\title{
Heterosis for Fruit Yield and Heat Tolerance Traits in Tomato (Lycopersicon Lycopersicum Mill.) Under Field Conditions
}

\author{
H. S. Hamisu (Corresponding author)
}

National Horticultural Research Institute, Bagauda Station, P.M.B 3390, Kano State, Nigeria. Corresponding author: saleh00073hamisu@gmail.com

\section{S. G. Ado}

Department of Plant Science, Institute for Agricultural Research, Ahmadu Bello University, P.M.B 1044, Samaru, Zaria, Nigeria.

$$
\text { M. Y. Yeye }
$$

Department of Plant Science, Institute for Agricultural Research, Ahmadu Bello University, P.M.B 1044, Samaru, Zaria, Nigeria.

\section{S. Usman}

Department of Plant Science, Institute for Agricultural Research, Ahmadu Bello University, P.M.B 1044, Samaru, Zaria, Nigeria.

\section{S. M. Mohammed}

Department of Plant Science, Institute for Agricultural Research, Ahmadu Bello University, P.M.B 1044, Samaru, Zaria, Nigeria.

\section{A. Usman}

Department of Plant Science, Institute for Agricultural Research, Ahmadu Bello University, P.M.B 1044, Samaru, Zaria, Nigeria. 
S. O. Afolayan

National Horticultural Research Institute, Ibadan, P.M.B 5432, Oyo State, Nigeria.

\title{
J. J. Yaduma
}

National Horticultural Research Institute, Bagauda Station, P.M.B 3390, Kano State, Nigeria.

\section{S. M. Mohammad}

National Horticultural Research Institute, Bagauda Station, P.M.B 3390, Kano State, Nigeria.

\author{
B. A. Idris
}

National Horticultural Research Institute, Bagauda Station, P.M.B 3390, Kano State, Nigeria.

\section{Y. Gwammaja}

National Horticultural Research Institute, Dadin Kowa, Gombe State, Nigeria.

A. H. Hudu

National Horticultural Research Institute, Bagauda Station, P.M.B 3390, Kano State, Nigeria.

N. B. Sanda

Department of Crop Protection, Bayero University, Kano

Received: January 29, 2018

Accepted: February 12, 2018

doi:10.5296/jas.v6i2.13047

URL: https://doi.org/10.5296/jas.v6i2.13047

\begin{abstract}
Field experiments were conducted at the National Horticultural Research Institute, Bagauda in the Sudan Savannah and Institute for Agricultural Research, Samaru in the Northern Guinea Savanna ecological zones of Nigeria between July-October, 2014 rainy season to estimates heterosis for fruit yield and heat tolerance traits of tomato under field conditions. The experiment comprised two heat tolerant (Icrixina and Rio Grande) and four heat susceptible tomato (Tima, Tropimech, Petomech and Roma Savana) which were crossed
\end{abstract}


using half diallel mating design in the screen house. The resultant 15 hybrids, their parental lines along with four checks were laid out in partially balanced lattice design with three replications. Analysis of variance revealed significant variation among the genotypes for all traits except fruit diameter and cell membrane thermostability, indicating sufficient variability existed among the genotypes. The cross combinations Icrixina $\times$ Rio Grande, Icrixina $\times$ Tima, Icrixina $\times$ Roma Savana and Icrixina $\times$ Petomech were found heterotic over better parent for fruit yield and heat tolerance traits (Number of branches per plant, number of clusters per plant, number of flowers per cluster, number of fruits per cluster, number of fruits per plant, percentage fruit set and chlorophyll content) among the hybrids. These hybrids were superior over better parent have the potentiality to be exploited for developing commercial heat tolerant tomato hybrid under field conditions.

Keywords: Diallel mating design, Heat tolerance, Fruit yield, Tomato.

\section{Introduction}

Tomato (Lycopersicon lycopersicum) belongs to the family Solanaceae, genus Lycopersicon, subfamily Solanoideae and tribe Solaneae (Taylor, 1986). It is very rich in vitamins, minerals, essential amino acids, sugars and dietary fibers. Tomato contains a high level of lycopene, an antioxidant that reduces the risks related to several cancers and neurodegenerative diseases (Srinivasan, et al., 2010). Heterosis is the vigor manifested in hybrids and represents the superiority in performance of hybrid individuals compared to their parents. The $\mathrm{F}_{1}$ hybrid of tomatoes is one of most leading vegetable crops all over the world (Patwary et al., 2013). Heterosis is a widely documented phenomenon in tomato with more than 50-60\% of the studies on heterotic performance referring to heterosis for yield and yield components and this percent was relatively stable even throughout the last decade (Bistra and Hristo, 2007). However, beside yield, enhanced plant vigor, faster growth and development, increased productivity, earlier maturity, high level of resistance to biotic and abiotic stresses and uniformity were the manifestation of heterosis most often encountered in tomato crop (Yordanov, 1983). Zhakote and Kharti (1990) reported heterosis for net photosynthesis production in hybrids between cultivated and wild forms of tomato; while, Titok et al. (1994) observed manifestation of heterosis for chlorophyll content, both in the leaves and stems and a higher level of heterosis was observed in the stems. Gaikwad and Cheema (2009) carried out studies on heterosis for quality traits in a $12 \times 12$ half diallel using twelve heat tolerant lines. They revealed that heterosis over better parent and the two standard checks were observed for all the traits and concluded that, for heat tolerant tomato, heterosis breeding may be the most prominent approach for quality improvement as most of the traits are governed by non-additive gene action. . Patwary et al. (2013) estimated heterosis of heat tolerant tomato in an $8 \times 8$ half diallel mating. They observed significant heterosis for plant height, days to $50 \%$ flowering, number of branches per plant, number of flowers per cluster, number of fruits per cluster, number of fruits per plant, fruit length, fruit diameter, percent fruit set, fruit weight and fruit yield per plant over the better parent. Enang et al. (2015) observed heterobeltiosis for plant height, number of flower clusters, number of fruit per plant and number of leaves among hybrids for heat tolerant. Camejo et al. (2005) reported that, the optimal temperatures required for tomato cultivation are between $25-30^{\circ} \mathrm{C}$ during daytime 
and $20^{\circ} \mathrm{C}$ during the dark period and an increase of $2-4^{\circ} \mathrm{C}$ over the optimal temperature adversely affects gamete development and inhibits the ability of pollinated flowers to develop into fruits and thus reduced fruit yield and size (Peet et. al., 1997, Sato, et. al., 2001; Firon, et. al., 2006). Foolad (2007) observed that heat stress due to high temperature becomes a major limiting factor for field production of tomatoes. Heat stress as a result of high temperature during growing season is detrimental to growth and reproductive development which reduces fruit size, yield and fruit quality (Abdul-Baki, 1991, Dane et al., 1991, Wessel-Beaver and Scott, 1992, Scott, 2000). In Nigeria, the major growing area of tomato lies between latitudes $7.5^{\circ} 11^{\prime}$ and $13.0^{\circ} \mathrm{N}$ and within a range temperature of $22-30^{\circ} \mathrm{C}$. Tomato is usually grown during harmattan and rainy season in Nigeria and high temperature during the rainy season caused a significant reduction of fruit size, increment in flower abortion, decrease in fruit set which reduced fruit yield and shortage of supply which results in high cost. Therefore, there is need to develop high yielding hybrids with acceptable fruit setting ability and size under high temperature through proper breeding program to bridge the gap of the demand of tomato during rainy season. The present investigation was conducted to identify best hybrid(s) for fruit yield and heat tolerance traits under field conditions.

\section{Material and Methods}

The experiment comprised two heat tolerant (Icrixina and Rio Grande) and four heat susceptible tomato (Tima, Tropimech, Petomech and Roma Savana) which were crossed using half diallel mating design in the screen house. The resultant 15 hybrids, 6 parents and 4 checks (Roma VF, UC82 B, Thorgal $F_{1}$ and Jaguar $F_{1}$ ) were evaluated at National Horticultural Research Institute, Bagauda Research Farm $\left(11^{\circ} 33^{\prime} \mathrm{N} ; 8^{\circ} 23^{\prime} \mathrm{E}\right)$ in the Sudan Savannah and Institute for Agricultural Research Farm, Samaru $\left(11^{0} 11^{\prime} \mathrm{N} ; 07^{0} 38^{\prime} \mathrm{E}\right)$ in the Northern Guinea Savanna ecological zones of Nigeria using $5 \times 5$ partially balanced lattice design with three replications; between July to October, 2014 rainy season to synchronize flowering stage with heat period (September and October) as shown in Table 1. The plot size was $2 \times 2 \mathrm{~m}$ and $1 \mathrm{~m}$ alleys. Seedlings were raised in nursery and transplanted to the field about 30 days after sowing on three rows at inter-row spacing of $60 \mathrm{~cm}$ and intra-row of $50 \mathrm{~cm}$. Fertilizer (N.P.K 15:15:15) was split and applied at the rate of $45 \mathrm{kgN}, 45 \mathrm{~kg}_{2} \mathrm{O}_{5}$ and $45 \mathrm{kgK}_{2} \mathrm{O} / \mathrm{ha}$ and Urea $(46 \%)$ at the rate of $64.4 \mathrm{kgN} / \mathrm{ha}$ at two and five weeks after transplanting, respectively. All agronomic practices were kept uniform in all plots, according to National Horticultural Research Institute agronomic practices. Data were randomly taken on five plants for observations and measurements leaving the plants on either end of the plot to avoid the border effect. Data were recorded for plant height, days to $50 \%$ flowering, number of branches per plant, number of clusters per plant, number of flowers per cluster, number of flowers per plant, number of fruits per cluster, number of fruits per plant, average fruit weight, fruit length, fruit diameter, fruit shape index, fruit yield per plant, percentage fruit set and, leaf chlorophyll content, canopy temperature depression and cell membrane thermostability. The leaf chlorophyll content was measured using SPAD chlorophyll meter (SPAD 502plus. Konica Minolta, Tokyo, Japan). Canopy temperature depression was recorded using handheld infrared Thermometer (Spectrum Technologies, Inc. U.S.A) and calculated using equation 1. Cell membrane thermostability test was conducted according to 


\section{Macrothink}

Journal of Agricultural Studies

ISSN 2166-0379

2018, Vol. 6, No. 2

Kuo, et al. (1993). Ten leaf disks of $10 \mathrm{~mm}$ diameter were punched from new uppermost leaves of each genotype from each replication. The leaf disks were washed three times with distilled water to remove electrolytes from the injured cell at the cut edge and any surface adhering electrolytes. Leaf disks were then placed in a $20 \mathrm{ml}$ test tube and $10 \mathrm{ml}$ deionized water was added. The test tubes were covered and incubated in a water bath (Waterbath TT60D Multipurpose, Techmel and Techmel, U.S.A) at $30^{\circ} \mathrm{C}, 40^{\circ} \mathrm{C}$ and $50^{\circ} \mathrm{C}$ for an hour, while control tubes were maintained at $25^{\circ} \mathrm{C}$ at the same time period. After incubation in a water bath, the test tubes were cooled to room temperature and then electrolyte conductivity of the solutions was measured using an electrical conductivity meter (Waterproof EC Meter, Spectrum Technologies. Inc. U.S.A). After initial readings, the test tubes were then boiled for 30 minutes to completely kill leaf tissue and release all of the electrolytes. The test tubes were cooled to $25^{\circ} \mathrm{C}$ and final electrolyte conductivities were measured. The cell membrane thermostability and relative high temperature injury were estimated using equations 2 and 3. The genotypes were classified according to Kuo, et al. (1993) as follows: Heat tolerant (HT): $\mathrm{HI}<25 \%$, moderately heat tolerant (MHT): $25 \%<\mathrm{HI}<50 \%$, slightly heat tolerant (SHT): $50 \%<\mathrm{HI}<75 \%$, heat sensitive (HS): HI $>75 \%$. Analysis of variance was computed using computer statistical software (SAS Institute, 2004). Heterosis for individual crosses was estimated based on the difference between $F_{1}$ and their parents. Better parent heterosis (heterobeltiosis) was calculated for each individual hybrid according to Hayes et al. (1965) equation 4:

$$
\text { Canopy temperature depression }=T_{a}-T_{c}
$$

Where:

$T_{a}=$ Air temperature

$T_{c}=$ canopy temperature

Cell membrane thermostability $(\%)=\left[\left(1-\left(T_{1} / T_{2}\right) /\left(1-\left(C_{1} / C_{2}\right)\right] \times 100\right.\right.$

Relative heat injury $(\%)=100-$ CMS

Where C, T and CMS refer to the electrical conductivity of control, heat treated samples and cell membrane stability, respectively. The subscript 1 and 2 refer to electrical conductivity readings before and after boiling, respectively.

$$
\text { Heterobeltiosis }=\frac{\left(F_{1}-B_{P}\right)}{B_{P}} \times 100
$$

Where:

$F_{1}=$ Average performance of hybrid formed between $j^{t h}$ and $i^{t h}$ parents .

$B_{P}=$ Average performance of the better parent. 


\section{MInstitute Macrothink $_{\text {Int }}$}

Journal of Agricultural Studies

ISSN 2166-0379

2018, Vol. 6, No. 2

The significance of better parent heterosis was tested using the formula of Wynne et al. (1970). The Calculated t was tested against the Table value of $t$ at error d.f for tests of significance.

$$
\text { S.E. }(B P)=\sqrt{\frac{2 \sigma_{\mathrm{e}}^{2}}{r}}
$$

$$
t_{\text {value }}=\frac{\text { Heterobeltiosis }}{\text { S.E. }(B P)}
$$

Where

S.E. $(\mathrm{BP})=$ Standard error between $\mathrm{F}_{1}$ and better parent required for significance at $5 \%$ and $1 \%$ probability levels.

$\sigma_{e}^{2}=$ Error mean squares

$r=$ Number of replications

\begin{tabular}{|c|c|c|c|c|c|c|}
\hline \multirow[t]{2}{*}{ Month } & \multicolumn{3}{|c|}{ Bagauda } & \multicolumn{3}{|c|}{ Samaru } \\
\hline & $\begin{array}{c}\text { Maximum } \\
\text { Temperature } \\
\text { (oC) }\end{array}$ & $\begin{array}{c}\text { Minimum } \\
\text { Temperature } \\
\text { (oC) }\end{array}$ & $\begin{array}{c}\text { Rainfall } \\
\text { (mm) }\end{array}$ & $\begin{array}{c}\text { Maximum } \\
\text { Temperature } \\
\text { (oC) }\end{array}$ & $\begin{array}{c}\text { Minimum } \\
\text { Temperature } \\
\text { (oC) }\end{array}$ & $\begin{array}{c}\text { Rainfal } \\
(\mathrm{mm})\end{array}$ \\
\hline July & 32.2 & 22.6 & 24.06 & 30.9 & 22.38 & 11.71 \\
\hline August & 31 & 24.13 & 30.86 & 29.83 & 22.43 & 26.74 \\
\hline September & 32.67 & 27.11 & 14.07 & 31.17 & 21.72 & 11.04 \\
\hline October & 32.92 & 24 & 45.2 & 33.73 & 21.23 & 2.33 \\
\hline
\end{tabular}

Table 1: Average temperature and rainfall for the experimental sites

Source: National Horticultural Research Institute, Bagauda and Institute for Agricultural Research, Samaru, meteorological data units.

\section{Results and Discussion}

\subsection{Analysis of Variance}

Mean squares for fruit yield and heat tolerance traits combined across locations are presented in Table 2. The result indicated highly significant genotypic variation $(p \leq 0.01)$ for all traits, except fruit diameter and cell membrane thermostability, while canopy temperature depression was significant $(\mathrm{p} \leq 0.05)$. Significant variations among studied genotypes recorded for all traits indicating sufficient variability exists in the materials used for the study and also indicating possibility for selection of suitable breeding materials for heat tolerant tomato improvement under high temperature environments. Similar results were reported by Hazra and Ansary (2008), Kugblenu et al. (2013), Islam et al. (2014) and Enang et al. (2015).

Table 2: Mean squares for fruit yield and heat tolerance traits combined across locations during 2014

\begin{tabular}{|c|c|c|c|c|c|c|c|c|c|}
\hline Source of variation & df & PHT & DFPFL & NBPP & NCPP & NFLPC & NFLPP & NFRPC & NFRPP \\
\hline Location & 1 & $6084.75^{* *}$ & $74.91 * *$ & $7408.92 * *$ & $1912.66 * *$ & 0.52 & $182490.07 * *$ & 0.02 & 8198.32 ** \\
\hline $\begin{array}{l}\text { Block(replication } \times \\
\text { location) }\end{array}$ & 24 & 73.19 & 12.56 & 49.26 & 14.56 & 0.53 & 232.19 & 0.73 & 52.44 \\
\hline
\end{tabular}
rainy season 


\begin{tabular}{lccccccccc}
\hline Replication(location) & 4 & 128.97 & 10.17 & 39.59 & 14.23 & 0.78 & 796.08 & 0.28 & 91.45 \\
Genotype & 24 & $138.51^{* *}$ & $27.53^{* *}$ & $74.18^{* *}$ & $57.40^{* *}$ & $3.01^{* *}$ & $1535.64^{* *}$ & $1.86^{* *}$ & $200.66^{* *}$ \\
Genotype $\times$ location & 24 & $80.47^{*}$ & 8.81 & $54.51^{* *}$ & $12.91^{*}$ & 0.13 & $639.14^{* *}$ & 0.02 & 36.01 \\
Error & 72 & 42.13 & 5.53 & 11.65 & 6.85 & 1.09 & 205.10 & 0.31 & 33.15 \\
\hline
\end{tabular}

$\mathrm{df}=$ Degrees of freedom, PHT $=$ Plant height, DFPFL $=$ Days to $50 \%$ flowering, $\mathrm{NBPP}=$ Number of branches per plant, NCPP $=$ Number of clusters per plant, NFLPC $=$ Number of flowers per cluster, NFLPP $=$ Number of flowers per plant, NFRPC $=$ Number of fruits per cluster and NFRPP $=$ Number of fruits per plant. ** and * are significantly different at $1 \%$ and $5 \%$ levels of probability, respectively.

Table 2 continued

\begin{tabular}{|c|c|c|c|c|c|c|c|c|c|c|}
\hline Source of variation & $\mathrm{df}$ & AFW & FRL & FRD & FRSI & FRYPP & PFRS & LCC & CTD & CMT \\
\hline Location & 1 & 29.06 & 0.57 & 0.69 & 0.01 & $6507841.92 * *$ & $1082.13 * *$ & $3080.85^{* *}$ & $338.19 * *$ & $1026.99 *$ \\
\hline $\begin{array}{l}\text { Block(replication } \times \\
\text { location) }\end{array}$ & 24 & 198.45 & 0.30 & 0.13 & 0.04 & 23057.13 & 38.21 & 70.80 & 2.59 & 94.16 \\
\hline Replication(location) & 4 & 255.96 & 0.40 & 1.23 & 0.16 & 1921.78 & 56.10 & 151.88 & 10.65 & 18859.30 \\
\hline Genotype & 24 & $325.04 * *$ & $2.36 * *$ & 0.12 & $0.20 * *$ & $66310.62 * *$ & $491.53 * *$ & $71.41 * *$ & $4.23 *$ & 214.88 \\
\hline Genotype $\times$ location & 24 & 136.43 & 0.31 & 0.04 & 0.03 & 16974.22 & $213.03 * *$ & $109.22 * *$ & 4.01 & 218.13 \\
\hline Error & 72 & 99.24 & 0.25 & 0.12 & 0.03 & 14090.34 & 69.53 & 42.67 & 2.47 & 205.64 \\
\hline
\end{tabular}

$\mathrm{AFW}=$ Average fruit weight, FRL $=$ Fruit length, FRD $=$ Fruit Diameter, FRSI $=$ Fruit shape index, FRYPP $=$ Fruit yield per plant, PFRS $=$ Percentage fruit set, LCC $=$ Leaf chlorophyll content, CTD = Canopy temperature depression and CMT $=$ Cell membrane thermostability. $* *$ and $*$ are significantly different at $1 \%$ and $5 \%$ levels of probability, respectively.

\subsection{Heterosis}

The estimates of heterobeltiosis combined across locations show that the degree and magnitude of heterobeltiosis varied from hybrid to hybrid and from trait to trait. However, both positive and negative heterotic values were observed among the traits.

\subsubsection{Plant height}

The heterosis over better parent for plant height ranged from $-12.69 \%$ (Tropimech $\times$ Petomech) to $9.25 \%$ (Roma Savana $\times$ Petomech). Among all the hybrids, only Tropimech $\times$ Petomech showed significant negative heterobeltiosis, indicating existing genetic variability for the traits. Similar results were reported by Yadav et al. (2013), Enang et al. (2015) and Khan and Jindal (2016).

\subsubsection{Days to $50 \%$ flowering}

The magnitude of heterosis over better parent for days to $50 \%$ flowering varied from $-8.92 \%$ $($ Icrixina $\times$ Tropimech) to $6.59 \%$ (Tima $\times$ Roma Savana). Out fifteen hybrids, two hybrids exhibited significant positive heterosis, while three hybrids expressed significant negative heterosis over the better parent. Negative heterobeltiosis recorded for days to $50 \%$ flowering is desirable because of their breeding value for developing early flowering tomato hybrids which could escape heat stress. Patwary et al. (2013), Enang et al. (2015) and Welegama et al. 
(2015) reported significant negative heterobeltiosis for days to $50 \%$ flowering.

\subsubsection{Number of branches per plant}

Significant positive heterosis regarding number of branches per plant was observed in eight hybrids revealing that number of branches could be improve through heterosis breeding. The highest positive heterosis was observed for Icrixina $\times$ Tropimech $(72.34 \%)$ followed by Icrixina $\times$ Tima (39.07\%), Icrixina $\times$ Rio Grande (38.49\%) and Tima $\times$ Tropimech $(36.63 \%)$. Four hybrids exhibited significant negative heterobeltiosis. The results corroborated with findings of Patwary et al. (2013), Yadav et al. (2013)

\subsubsection{Number of clusters per plant}

The heterobeltiosis for the number of clusters per plant ranged from $-46.76 \%$ (Rio Grande $\times$ Roma Savana) to $31.20 \%$ (Icrixina $\times$ Rio Grande). Seven hybrids indicated positive heterosis over the better parent. Similar findings were reported by Amaefula et al. (2014) and Enang et al. (2015).

\subsubsection{Number of flowers per cluster}

Out of fifteen hybrids, eleven showed significant positive heterobeltiosis indicating the parents were from diverse origin. The heterobeltiosis varied from $-18.15 \%$ (Tropimech $\times$ Roma Savana) to $21.30 \%$ (Rio Grande $\times$ Roma Savana). The result was in accordance with findings of Gul et al. (2010), Patwary et al. (2013) and Enang et al. (2015).

\subsubsection{Number of flowers per plant}

Three hybrids expressed significant negative heterosis over better parent for number of flowers per plant. The values ranged from $-36.15 \%$ (Rio Grande $\times$ Roma Savana) to $20.13 \%$ (Petomech $\times$ Roma Savana). This an indication that the parents were probably from the same origin regarding number of flowers per plant.

\subsubsection{Number of fruits per cluster}

Highly significant positive heterobeltiosis was manifested in eleven hybrids, while significant negative heterobeltiosis was observed in three hybrids, revealing that the parents were from diverse origin for number of fruits per cluster. Rio Grande $\times$ Tima had no heterotic effect over the better parent. It ranged from $-10.62 \%$ (Rio Grande $\times$ Tropimech) to $26.93 \%$ (Icrixina $\times$ Rio Grande). Gul et al. (2010), Ahmad et al. (2011), Patwary et al. (2013) and Amaefula et al. (2014) reported both significant positive and negative heterobeltiosis for number of fruits per cluster.

\subsubsection{Number of fruits per plant}

Five hybrids showed significant positive heterosis, while eight hybrids expressed significant negative heterosis over the better parent. The better parent heterosis ranged from $-66.79 \%$ (Rio Grande $\times$ Roma Savana) to $26.08 \%$ (Petomech $\times$ Roma Savana). The hybrids exhibited significant positive heterosis over better parent could be selected and their parents could also consider for developing hybrid heat tolerant tomato under field conditions in both locations. 
The result was in accordance with findings of Patwary et al. (2013), Enang et al. (2015), Aisyah et al. (2016), Khan and Jindal (2016) and Kumar et al. (2016) while El-Saka Zeinab (2016) reported significant negative heterosis over the better parent for all hybrids under heat stress.

\subsubsection{Average fruit weight}

The better parent heterosis for average fruit weight varied from $-21.26 \%$ (Icrixina $\times$ Tropimech) to $29.41 \%$ (Icrixina $\times$ Petomech). Out of fifteen hybrids, only Icrixina $\times$ Petomech and Rio Grande $\times$ Roma Savana revealed significant positive heterosis over better parent. Similar findings were observed by Kumar et al. (2012), Yadav et al. (2013), Khan and Jindal (2016) and Kumar et al. (2016).

\subsubsection{Fruit length}

The heterobeltiosis for fruit length ranged from $-28.99 \%$ (Icrixina $\times$ Rio Grande) to $6.52 \%$ (Rio Grande $\times$ Roma Savana). Five hybrids showed significant positive heterosis over the better parent. The record for low percent of heterosis over better parent could be attributable to similar genetic base of the materials used for the development of the parents. Kumar et al. (2016) reported significant positive heterobeltiosis whereas Amaefula et al. (2014) observed significant negative heterosis over better parent among all hybrids.

\subsubsection{Fruit diameter}

Better parent heterosis for fruit diameter varied from $-9.16 \%$ (Icrixina $\times$ Rio Grande) to $3.96 \%$ (Rio Grande $\times$ Petomech). Out of fifteen hybrids, only four hybrids revealed significant positive heterosis over better parent. Icrixina $\times$ Roma Savana had no heterotic effect over the better parent. Aisyah et al. (2016) and Kumar et al. (2016) reported significant positive heterobeltiosis for fruit diameter.

\subsubsection{Fruit shape index}

Significant positive heterobeltiosis were observed in five hybrids. The heterobeltiosis effects ranged from $-26.03 \%$ (Icrixina $\times$ Rio Grande) to $12.77 \%$ (Petomech $\times$ Roma Savana). The results corroborated with findings of Hussien (2014) and Khan and Jindal (2016).

\subsubsection{Fruit yield per plant}

The magnitude of heterosis over better parent varied from $-25.09 \%$ (Tropimech $\times$ Roma Savana) to $58.65 \%$ (Icrixina $\times$ Rio Grande). None of the hybrids exhibited significant difference among them. However, the Icrixina $\times$ Rio Grande $(58.65 \%)$ showed maximum positive heterosis followed by Icrixina $\times$ Petomech $(20.53 \%)$, Icrixina $\times$ Tima $(19.49 \%)$ and Icrixina $\times$ Roma Savana (17.17), while the lowest positive heterobeltiosis was recorded for Rio Grande $\times$ Petomech (2.82\%). Hussien (2014) and Aisyah et al. (2016) reported heterosis over better parent for fruit yield per plant.

\subsubsection{Percentage fruit set}

Significant positive heterosis regarding percentage fruit set was observed in four hybrids. 


\section{$\triangle$ Macrothink}

Journal of Agricultural Studies

ISSN 2166-0379

2018, Vol. 6, No. 2

These hybrids were crosses involving one or both heat tolerant parents and can be utilized for yield and heat tolerant tomato improvement in high temperature locations. The heterobeltiosis varied from $-27.68 \%$ (Rio Grande $\times$ Roma Savana) to $73.05 \%$ (Icrixina $\times$ Rio Grande). These results are in conformity with findings of Patwary et al. (2013), while El-Saka Zeinab (2016) reported significant negative heterosis over the better parent of fruit set for all hybrids under heat stress.

\subsubsection{Leaf chlorophyll content}

Heterosis over better parent for leaf chlorophyll content ranged from $-13.65 \%$ (Rio Grande $\times$ Tima) to $13.56 \%$ (Icrixina $\times$ Roma Savana). Out of fifteen hybrids, only two revealed significant positive heterosis, whereas two hybrids expressed significant negative heterobeltiosis. Singh and Asati (2011) observed significant negative heterobeltiosis for leaf chlorophyll content.

\subsubsection{Canopy temperature depression}

The heterobeltiosis for canopy temperature depression varied from $-15.86 \%$ (Icrixina $\times$ Petomech) to $4.12 \%$ (Icrixina $\times$ Tropimech). All the hybrids except Icrixina $\times$ Tropimech $(4.12 \%)$ recorded highly significant negative heterosis over the better parent.

\subsubsection{Cell membrane thermostability}

None among the hybrids recorded significant heterobeltiosis regarding cell membrane thermostability at $30^{\circ} \mathrm{C}$. The heterobeltiosis varied from $-49.38 \%$ (Tima $\times$ Petomech) to $9.53 \%$ (Icrixina $\times$ Tima). Significant positive heterobeltiosis were observed in five hybrids at $40^{\circ} \mathrm{C}$. The heterobeltiosis effects ranged from $-76.53 \%$ (Petomech $\times$ Roma Savana) to $49.81 \%$ (Petomech $\times$ Roma Savana). Out of fifteen hybrids, only three hybrids revealed significant positive heterosis, whereas five hybrids expressed significant negative heterobeltiosis at $50^{\circ} \mathrm{C}$. The heterobeltiosis for cell membrane thermostability at $50^{\circ} \mathrm{C}$ varied from $-64.68 \%$ (Icrixina $\times$ Petomech) to $115.25 \%$ (Rio Grande $\times$ Roma Savana).

Table 3: Percent better parent heterosis of hybrids for fruit yield and heat tolerance traits across locations during 2014 rainy season

\begin{tabular}{|c|c|c|c|c|c|c|c|c|c|}
\hline Hybrid & PHT & DFPFL & NBPP & NCPP & NFLPC & NFLPP & NFRPC & NFRPP & AFW \\
\hline Icrixina $\times$ Rio Grande & 2.61 & $-5.04 * *$ & $38.49 * *$ & $31.20 * *$ & $14.85^{* *}$ & 3.65 & $26.93^{* *}$ & $16.12 * *$ & -2.31 \\
\hline Icrixina $\times$ Tima & 3.50 & -3.54 & $39.07 * *$ & $15.08 * *$ & $5.69 * *$ & -3.30 & $19.87 * *$ & $15.07 * *$ & -10.06 \\
\hline Icrixina $\times$ Tropimech & -1.46 & $-8.92 * *$ & $72.34 * *$ & $15.86^{* *}$ & $12.48 * *$ & -4.72 & $25.17 * *$ & 8.54 & $-21.26^{*}$ \\
\hline Icrixina $\times$ Petomech & 7.41 & -1.19 & $10.66 * *$ & $9.20 * *$ & 0.63 & -1.95 & $26.49 * *$ & $17.12 * *$ & $29.41 * *$ \\
\hline Icrixina $\times$ Roma Savana & -4.82 & -0.48 & -2.23 & $18.35 * *$ & $16.43 * *$ & -9.91 & $14.79 * *$ & $10.24 *$ & -4.10 \\
\hline Rio Grande $\times$ Tima & 3.44 & 0.00 & 1.09 & -3.96 & $12.07 * *$ & $-32.60 *$ & 0.00 & -5.48 & -9.10 \\
\hline Rio Grande $\times$ Tropimech & 6.97 & -0.94 & $-13.08 * *$ & $8.05 * *$ & $-16.20 * *$ & -18.03 & $-10.62 * *$ & $-16.18 * *$ & $-18.05^{*}$ \\
\hline Rio Grande $\times$ Petomech & 7.08 & $4.54 *$ & $-14.36^{* *}$ & $-9.58 * *$ & $7.16^{* *}$ & -13.05 & $4.68 * *$ & $-20.04 * *$ & 3.39 \\
\hline Rio Grande $\times$ Roma Savana & -10.23 & -0.48 & $-38.04 * *$ & $-46.76^{* *}$ & $21.30 * *$ & $-36.15^{* *}$ & $13.08 * *$ & $-66.79 * *$ & $24.86^{* *}$ \\
\hline Tima $\times$ Tropimech & 0.20 & -1.87 & $36.63 * *$ & 3.43 & $13.04 * *$ & 9.90 & $11.42^{* *}$ & $-10.00 *$ & -13.20 \\
\hline Tima $\times$ Petomech & -0.80 & -2.83 & $7.26^{*}$ & $4.36^{*}$ & $5.36 * *$ & -14.79 & $4.23 * *$ & $-11.56^{*}$ & -14.08 \\
\hline
\end{tabular}




\begin{tabular}{lccccccccc}
\hline Tima $\times$ Roma Savana & 5.15 & $6.59 * *$ & $-24.24 * *$ & $-28.06 * *$ & $14.26 * *$ & 3.76 & $4.23 * *$ & $-17.63 * *$ & -8.33 \\
Tropimech $\times$ Petomech & $-12.69 *$ & 1.87 & 5.03 & $-9.58^{* *}$ & 0.56 & $-25.34 *$ & $-4.62 * *$ & $-12.55^{*}$ & 5.07 \\
Tropimech $\times$ Roma Savana & -2.92 & 2.82 & $21.46^{* *}$ & $-23.35 * *$ & $-18.15 * *$ & -7.20 & $-7.62 * *$ & $-32.74 * *$ & -14.58 \\
Petomech $\times$ Roma Savana & 9.25 & $-4.25 *$ & $7.01 *$ & -0.12 & $5.19 * *$ & 20.13 & $12.41 * *$ & $26.08 * *$ & -11.37 \\
\hline SE \pm & 5.210 & 1.920 & 2.787 & 2.137 & 0.852 & 11.693 & 0.455 & 4.701 & 8.134 \\
\hline
\end{tabular}

$\mathrm{PHT}=$ Plant height, DFPFL $=$ Days to $50 \%$ flowering, NBPP $=$ Number of branches per plant, NCPP $=$ Number of clusters per plant, NFLPC $=$ Number of flowers per cluster, NFLPP $=$ Number of flowers per plant, NFRPC $=$ Number of fruits per cluster, NFRPP $=$ Number of fruits per plant and AFW $=$ Average fruit weight. ** and * are significantly different at $1 \%$ and $5 \%$ levels of probability, respectively. 
Table 3 continued

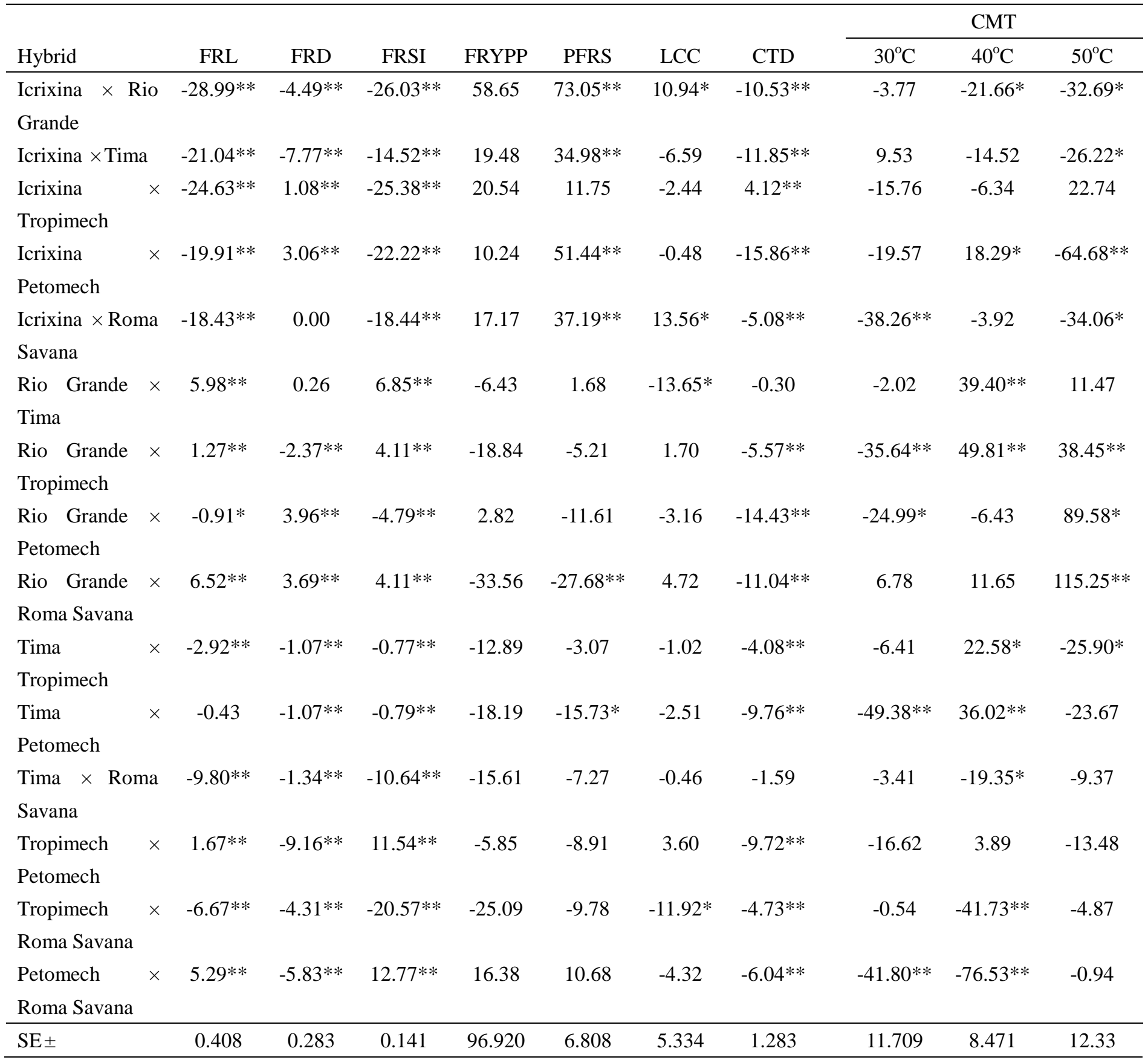

$\mathrm{FRL}=$ Fruit length, FRD = Fruit Diameter, FRSI = Fruit shape index, FRYPP = Fruit yield per plant, PFRS = Percentage fruit set, LCC = Leaf chlorophyll content, CTD = Canopy temperature depression and CMT $=$ Cell membrane thermostability. $* *$ and $*$ are significantly different at $1 \%$ and $5 \%$ levels of probability, respectively. 


\section{Conclusion}

The hybrids Icrixina $\times$ Rio Grande, Icrixina $\times$ Tima, Icrixina $\times$ Roma Savana and Icrixina $\times$ Petomech were found heterotic over better parent for fruit yield and heat tolerance traits. These hybrids were superior over better parent have potentiality to be exploited for developing commercial heat tolerant tomato hybrid under field conditions.

\section{References}

Abdul-Baki, A.A. (1991). Tolerance of Tomato Cultivars and Selected Germplasm to Heat Stress. Journal American Society of Horticultural Science, 116: 1113-1116.

Khan. A. and Jindal S.K. (2016) Exploiting yield potential in tomato (Solanum lycopersicum L.) through heterosis breeding, Plant Gene and Trait, 7(8): 1-7 (doi: 10.5376/pgt.2016.07.0008).

Ahmad, S., Quamruzzaman, A. K. M. And Islam, M. R. (2011). Estimate of Heterosis in Tomato (Solanum lycopersicum L.). Bangladesh Journal of Agricultural Research, 36(3): 521-527.

Aisyah S.I., Wahyuni S., Syukur M., Witono J.R. (2016). The estimation of combining ability and heterosis effect for yield and yield components in tomato (Solanum lycopersicum Mill.) at lowland. Ekin Journal, 2(1):23-29.

Amaefula, C., Agbo, C.U. and Nwofia, G.E. (2014). Hybrid Vigour and Genetic Control of Some Quantitative Traits of Tomato (Solanum lycopersicum L.). Open Journal of Genetics, 4, 30-39.

Bistra and Hristo. (2007). Expression of Heterosis by hybridization. In M.K. Razdan and A.K. Mattoo (Eds.), Genetic improvement of solanaceous Crops, Volume 2: Tomato (pp. 113-153). U.S.A: Science Publisher

Camejo D., Rodriguez P., Morales A.M., Amico J.M., Torrecillas A. and Alarcon J.J. (2005). High temperature effects on photosynthetic activity of two tomato cultivars with different susceptibility. Journal of Plant Physiology; 162:281-289.

Dane, F., Hunter, A.G. and Chambliss, O.L. (1991). Fruit set, pollen fertility, and combining ability of selected tomato genotypes under high-temperature field conditions. Journal American Society of Horticultural Science, 116: 906-910.

EL-Saka Zeinab, I. (2016). Tomato Breeding for Heat Stress Conditions. European Journal of Academic Essays, 3(2): 87-93,

Enang E.M., Kadams A.M., Simon S.Y., ang Louis S.J. (2015). Heterrosis and General Combining Ability Study on Heat Tolerant Tomato (Lycopersicon esculentum Mill) International Journal of Horticulture, 2015, Vol.5, No.17 1-7 (doi: 10.5376/ijh.2015.05.0017).

Firon, N., Shaked, R., Peet, M.M, Phari, D.M., Zamskı, E., Rosenfeld, K., Althanand, L. and Pressman, N.E. (2006). Pollen Grains of Heat Tolerant Tomato Cultivars Retain Higher 
Carbohydrate Concentration Under Heat Stress Conditions. Science Horticulture, 109:212-217.

Foolad, M.R. (2007). Tolerance to abiotic Stresses. In M.K. Razdan and A.K. Mattoo (Eds.), Genetic improvement of solanaceous Crops, Volume 2: Tomato (pp. 522-590). U.S.A: Science Publisher.

Gaikwad, A. K. and Cheema, D.S. (2009). Heterosis for Quality Traits using Heat Tolerant Lines in Tomato (Solanum lycopersicum L.). Indian Journal of Ecology, 36(2): 118-122.

Hayes, H.K., Immer, I.R, and Smith, D.C. (1965). Methods of plant breeding, McGraw Hill Company, Inc., New York.

Hazra, P. and Ansary, S.H. (2008). Genetics of heat tolerance for floral and fruit set to high temperature stress in tomato (Lycopersicon esculentum mill.). SABRAO Journal of Breeding and Genetics, 40(2): 117-125.

Hussien, A.H. (2014). Combining ability, Heterosis and Path Coefficient Analyses for Yield and its Components in Tomato. Egypt Journal Plant Breeding. 18(4):737 - 753.

Islam, M.S., Ahmed, S., Uddin, M.N, Rafi, M.Y., Ismail, M.A. and Malek, M.A. (2014). Identification of tomato inbred lines for heat tolerance through agronomic and physiological approaches. Journal of food, Agriculture and Environment, 12(1) 281-284.

Kugblenu, Y.O., Dansob, E.O., Oforia, K., Andersend, M.N., Abenney-Micksonb, S., Sabib, E.B., Plauborgd, F., Abekoec, M.K., Ofosu-Anima, J., Rodomiro Ortize and Jørgensenf, S.T. (2013). Screening tomato genotypes for adaptation to high temperature in West Africa. Acta Agriculturae Scandinavica, Section B - Soil \& Plant Science, 63:6, 516-522. doi: 10.1080/09064710.2013.813062.

Kumar, R., K. Srivastava, J. Somappa, Sunil Kumar and R. K. Singh. (2012). Heterosis for yield and yield components in Tomato (Lycopersicon esculentum Mill). Electronic Journal of Plant Breeding, 3(2): 800-805.

Kumar, P., Paliwal, A., Pant, S.C., Bahuguna, P. and Abrol, G. (2016). Heterosis studies in tomato (Lycopersicon esculentum mill.) for yield and yield attributing traits for further implications in crop improvement. Journal of Biological Innovation, 5(6): 959-972.

Patwary, M.M.A., M. M. Rahman., S. Ahmad, M. A. Khaleque M. and Barua H. (2013). Study of Heterosis in Heat Tolerant Tomato (Solanum lycopersicum) During Summer. Bangladesh Journal of Agricultural Research, 38(3): 531-544.

Peet M.M., Willits D.H. and Gardner R.G. (1997). Response of ovule development and post pollen production processes in male-sterile tomatoes to chronic, sub-acute high temperature stress. Journal of Experimental Botany; 48:101-111.

Sato, S., Peet, M.M. and Gardner, R.G. (2001). Formation of parthenocarpic fruit, undeveloped flowers and aborted flowers in tomato under moderately elevated temperatures. Science Horticulture, 90:243-254. 


\section{MInstitute Macrothink $^{\text {Int }}$}

Journal of Agricultural Studies

ISSN 2166-0379

2018, Vol. 6, No. 2

Scott, J.W. (2000). A Medium-Large, Heat Tolerant, Joint less-Pedicel Tomato. Horticultural Science, 35: 968-969.

Singh, A. K. and Asati, B. S. (2011). Combining Ability and Heterosis Studies in Tomato Under Bacterial Wilt Condition. Bangladesh Journal Agricultural Research, 36(2): 313-318.

Srinivasan, R. (Ed.). (2010). Safer Tomato Production Methods: A field Guide for soil fertility and pest management. AVRDC- The World Vegetable Center, Shanhua, Taiwan. AVRDC Publication No. 10-740. Pp. 2.

Taylor, I.B. (1986). Biosystematics of the tomato. In: Atherton, J. and Rudich, G. (eds). The Tomato Crop. A Scientific Basis for Improvement. Chapman \& Hall, New York.

Titok, V.V., Lemesh, V.A., Rusinova, O.V., and Podlisskikh, V.L. (1994). Leaf area, chlorophyll content and biomass of tomato plants and their heterotic hybrids under in vitro culture. Photosynthetica. 30:255-260.

Welegama, H.M.V.T., Jayarathna, R.G.Y.H., Alwis, L.M.H.R and Fonseka, H. (2015). Estimation of combining ability, heritability and Heterosis in tomato (Solanum lycopersicum 1.) Using full Diallel mating design. Annals of Sri Lanka Department of Agriculture, 17: 242-259.

Wessel-Beaver, L. and Scott J.W. (1992). Genetic variability of fruit set, fruit weight and yield in a tomato population grown in two high temperature environments. Journal of American Society of Horticultural Science, 117: 867-870.

Wynne, J.C., Emery, D.A. and Rice, P.M. (1970). Combining ability estimates in Arachis hypogaea L. II. Field performance hybrids. Crop Science 10(6): 713-715.

Yadav, S.K., Singh, B.K., Baranwal, D.K., and Solankey, S.S. (2013). Genetic study of heterosis for yield and quality components in tomato (Solanum lycopersicum). African Journal of Agricultural Research, 8(44): 5585-5591.

Yordanov, M. (1983). Heterosis in tomato. In: R. Frankel (ed.). Monographs on Theoretical and Applied Genetics, 6: 189-219.

Zhakote, A.G. and V.G. Kharti. (1990). Features of photosynthesis in wild, semi cultivated and cultivated genotypes of tomato and their $F_{1}$ hybrids in relation to breeding for yield. Sel'skohozyaistvennaya Biologiya. 5:82-88.

\section{Copyright Disclaimer}

Copyright for this article is retained by the author(s), with first publication rights granted to the journal.

This is an open-access article distributed under the terms and conditions of the Creative Commons Attribution license (http://creativecommons.org/licenses/by/4.0/). 